\title{
STORYTELLING PADA PESERTA DIDIK TK SENYIUR INDAH SEMARANG BERMUATAN NILAI KARAKTER
}

\author{
TURAHMAT ${ }^{\prime}$, OKTARINA PUSPITA WARDANI², DAN RINA WIJAYANTI ${ }^{3}$ \\ Universitas Islam Sultan Agung \\ lintangsastra@unissula.ac.id, oktarinapw@unissula.ac.id, wijayanti@unissula.ac.id
}

Pertama Diterima: 22 September 2019

Bukti Akhir Diterima: 27 September 2019

\begin{abstract}
Abstrak
Mengatasi degradasi moral yang terjadi saat ini perlu adanya pembentukan pendidikan karakter pada usia dini. Penerapan pendidikan karakter bisa melalui bercerita, bernyanyi, dan lainnya. Guru mengajarkan pendidikan karakter, guru harus mengenalkan pengetahuan moral, perasaan dan perilaku melalui sikap. TK Senyiur Indah menggunakan Kurikulum 2013 dalam pembelajaran karena merupakan inovasi baru terhadap dunia pendidikan. Penerapan metode storytelling di sekolah mampu membuat siswa semakin cerdas. Metode ini menjadikan cerita sebagai media dalam pembelajaran bahasa. Penelitian ini menggunakan metode Penelitian Tindaklan Kelas (PTK)Hasil penelitian menunjukkan storytelling mampu mengembangkan pengetahuan siswa mengenai kesehatan dan obat. Pengenalan kesehatan diimpelmentasikan pada tema profesi. Usia yang potensial dalam pembentukan karakter ialah usia emas. Masa tumbuh kembang usia anak untuk membentuk karakter sekitar usia 0-5 tahun. Penngkatan sebanyak 40\%. Nilai tersebiut diperoleh dari nilai rata-rata Siklus 1 sebesar 59\% dan nilai rata-rata Siklus 2t 99\%. Sehingga ada perningkatan nilai secara signifikan. Terdapat peningkatan pada siklus 2, siswa mampu mendapatkan nilai diatas 80 sebanyak $99 \%$. Berdasarkan hasil penelitian menggunakan storytelling dengan tema profesi, dapat disimpulkan bahwa metode tersebut dapat meningkatkan pemahaman siswa mengenai obat dan profesi apoteker. Dari hasil penelitian dapat dikatakan bahwa metode storytelling mampu mengembangkan pengetahuan siswa mengenai kesehatan dan obat. Pengenalan kesehatan diimpelmentasikan pada tema profesi. Kriteria keberhasilan pada siklus 2 ditentukan oleh peneliti. Pengetahuan anak mengenai profesi apoteker di tingkatkan melalui metode storytelling bermuatan pendidikan karakter.
\end{abstract}

Kata kunci: storytelling, nilai karakter dan tema kesehatan

Abstract

Overcoming moral degradation that occurs today needs the formation of character education at an early age. The application of character education can be through storytelling, singing, and others. The teacher teaches character education, the teacher must introduce moral knowledge, feelings and behavior through attitudes. TK Senyiur Indah uses Curriculum 2013 in learning because it is a new innovation to the world of education. The application of storytelling methods in schools can make students more intelligent. This method makes the story as a medium in language learning. This study uses the Classroom Action Research (CAR) method. The results showed storytelling is able to develop students' knowledge about health and medicine. The introduction of health is implemented on the theme of the profession. The potential age for character formation is golden age. The growth and development of the child's age to form a character around the age of 0-5 years. Increase by 40\%. The value is obtained from the average value of Cycle 1 of $59 \%$ and the average value of Cycle $2 t 99 \%$. So there is a significant increase in value. There was an increase in cycle 2, students were able to get scores above 80 by $99 \%$. Based on the results of research using storytelling with professional themes, it can be concluded that the method can increase students' understanding of medicine and the pharmacist profession. From the results of the study it can be said that the storytelling method is able to develop students' knowledge about health and medicine. The introduction of health is implemented on the theme of the profession. Success criteria in cycle 2 are determined by researchers. Children's knowledge about the pharmacist profession is enhanced through storytelling methods with character education.

Keywords: storytelling, character values and health theme 


\section{PENDAHULUAN}

Bahasa memiliki peran yang penting dalam perkembangan pengetahuan, sosial maupun emosi siswa untuk menunjang keberhasilan pembelajaran. Melalui bahasa, seseorang mampu mendapatkan pengetahuan dari berbagai dunia. Pada aspek pembelajaran, bahasa memiliki peran sebagai alat untuk mempelajari berbagai ilmu yang diajarkan di sekolah. Sehingga, bahasa tak hanya digunakan dalam mempelajari hal-hal mengenai bahasa saja, tetapi ilmu pembelajaran lainnya. Pemanfaatan bahasa bisa dikembangkan diberbagai bidang. Selain pembelajaran, bahasa juga bisa dimanfaatkan dalam komukasi antara orang tua dan anak

Pembelajaran bahasa Indonesia khususnya, mampu meningkatkan kemampuan siswa dalam berkomunikasi dengan baik dn benar secara lisan dan tulis. Jenis pembelajaran bahasa meliputi membaca, menulis, menyimak dan berbicara. Berbicara merupakan kemampuan seseorang dalam menyampaian ide dan gagasan melalui lisan. Sedangkan menyimak ialah kemampuan seseorang dalam mengamati dan mendengarkan gagasan dan ide orang lain.

Semakin siswa diberi cerita semakin bertambah pula kosa kata yang di dapat. Perkembangan bahasa yang didapat oleh siswa lainnya ilah bertambahnya pengetahuan mengenai intonasi serta kalimat yang digunakan. Siswa mampu memanfaatkan pengetahuannya dalam interaksi sehari-hari sebagai alat komunikatif nyata. Pentingnya hal tersebut, siswa harus dibiasakan dengan berlatif berbicara. Sejalan dengan masalah tersebut, guru juga harus lebih menambah kosakata yang akan disampaikan ke siswa. Guru diharuskan banyak membaca dan berinteraksi dengan teman sejawat. Sehingga, meningkat pula jumlah kosa kata yang diperoleh guru.

Kegiatan berbicara dan menyimak dapat dipadu padankan untuk diterapkan pada anak usia dini. Anak mampu belajar dari menyimak pembicaraan orang tua maupun orang yang berada dalam lingku keluarga. Salah satu yang bisa dipakai ialah melalui bercerita. Bercerita mampu membuat siswa tertarik dengan pembelajaran yang diberikan oleh guru. Siswa juga mampu lebih mudah menangkap arti dan pesan yang ingin disampaikan oleh pencerita kepada penyimak yaitu siswa. Sehingga, pembelajaran dapat berlangsung dengan tujuan siswa mampu berbicara dan menyimak.

Simakan yang dilakukan oleh siswa digunakan untuk mendapatkan informasi baru yang dapat digunakan untuk melatih berbicara. Proses pembelajaran ini mampu membantu guru dalam menyampaikan materi. Tak lepas dari hal tersebut, orang tua juga bisa memanfaatkannya proses bercerita untuk merangsang anak untuk berbicara. Semakin anak diajak berbiacara atau bercerita semakin banyak pula kosa kata yang didapat. Sehingga, anak bisa lebih cepat belajar berbicara.

Sarana komunikasi yang diberikan merupakan aspek yang dapat menunjang perkembangan bahasa anak. Perkembangan bahasa anak memiliki peran yang komunikatif untuk sarana menyampaikan ide, perasaan serta pikiran kepada orang lain. Dengan aspek bahasa, anak akan mudah melakukan interaksi dengan teman sebayanya. Tujuan lainnya adalah mendapatkan pengalaman baru. Kemampuan bahasa anak pertama ialah anak mampu berbicara sehingga anak dapat bercerita.

Nilai karakter dilaksanakan oleh sekolah melalui pembelajaran. Hal tersebut dilakukan agar mampu meningkatkan karakter dan moral siswa. Nilai karakter tak hanya dilakukan di jenjang SD, SMP, SMA maupun Perguruan Tinggi. Hal tersebut sudah selayaknya dilakukan dari tahap sekolah 
dini yaitu TK. Alternatif pengimplementasian nilai karakter di sekolah dianggap tepat. Hal itu dikarenakan pendidikan merupakan cara jangka panjang dalam membangun generasi yang memiliki moral dan karakter yang kuat.

Mengatasi degradasi moral yang terjadi saat ini perlu adanya pembentukan pendidikan karakter pada usia dini. Penerapan pendidikan karakter bisa melalui bercerita, bernyanyi, dan lainnya. Guru mengajarkan pendidikan karakter, guru harus mengenalkan pengetahuan moral, perasaan dan perilaku melalui sikap. Siswa mampu memunculkan sifat seperti itu dalam pembentukan karakter yang sesuai. Siswa memiliki bentuk karakter yang berbeda-beda. Sehingga, guru dan orang tua menjembatani siswa membentuk karakter mereka.

Usia yang potensial dalam pembentukan karakter ialah usia emas. Masa tumbuh kembang usia anak untuk membentuk karakter sekitar usia 0-5 tahun. Masa tersebut disebut dengan masa keemasan, dimana perkembangan yang terjadi dalam diri anak. Fondasi disiapkan dalam menentukan masa depan sehingga mampu memperkirakan cara belajar yang tepat. Oleh karena itu, guru dan orang tua mempersiapkan anak dengan diberi keterampilan dan pengetahuan sesuai perkembangan usianya.

Menurut Kemendikbud Dirjen PAUDNI (2012: 15-16) tujuan Pendidikan Anak Usia Dini ialah mengembangkan semua potensi yang dimiliki oleh anak sejak dini. Persiapan tersebut bertujuan untuk hidup dan penyesuaian diri dengan lingkungan. Sejalan dengan hal tersebut kemedikbud (2012) menjelaskan mengenai tujuan pendidikan anak usia dini, meliputi a) menumbuhkembangkan pengetahuan sikap, pengetahuan dan keterampilan untuk mdapat menolong diri sendiri. kemandirian dan rasa tanggung jawab pada diri sendiri misalnya dalam hal merawat diri sndiri dan menjaga kondisi fisik, mengendalikan sikap emosiaonal serta membangun hubungan baik dengan orang lain. b) meletetakkan dasar-dasar belajar (learning how to learn). Hal tersebut dihubungkan dengan perkembangan dunia pendidikan melaluo empat pilar pendidikan UNESCO yaitu learning to know, learning to do, learning to be dan learning to live together yang diimplematasikan pada jenjang Taman Kanak-kanak.

Berdasarkan kurikulum 2013 (2014: 3), tentang karakteristik kurikulum 2013 PAUD pada point 1, menyatakan bahwa mengupayakan keseimbangan antara pengembangan sikap, pengetahuan, dan keterampilan sesuai dengan tahap perkembangan anak. Hal ini sesuai dengan hasil penelitian Kristiani tentang Implementasi pendidikan karakter pada pembelajaran bahasa di PG-TPA Alam Uswatun Khasanah, Sleman, Jogjakarta (2014: 11) bahwa, implementasi pendidikan karakter pada pembelajaran bahasa di PG-TPA Alam Uswatun Khasanah, Sleman, Jogjakarta dikelompokkan berdasarkan usia perkembangan anak.

Pembentukan karakter anak usia dini merupakan awal dari perkembangan kepribadian anak. Anak usia dini memiliki kemampuan dalam meniru. Sehingga, anak lebih ulung dalam hal meniru apa yang dilihat dan didengar. Perkembangan stimulus yang diberikan kepada anak secara optimal, sehingga perkembangan emosial anak juga optimal. Salah satu stimulus untuk anak ialah bercerita. Dengan bercerita, anak mampu belajar mengekspresikan bentuk emosi dan ekspresi.

Richard Eyre dan Linda dalam Gunawan (2012: 31), nilai yang benar dan diterima secara universal adalah nilai yang menghasilkan suatu perilaku dan perilaku itu berdampak positif, baik bagi yang menjalankan maupun orang lain. Indonesian Heritage Foundation (IHF), merumuskan 
sembilan karakter dasar yang menjadi tujuan pendidikan karakter, yaitu (1) cinta kepada Allah dan semesta beserta isinya, (2) tanggungjawab, disiplin dan mandiri, (3) jujur, (4) hormat dan santun, (5) kasih sayang, peduli dan kerjasama, (6) percaya diri, kreativ, kerja keras, dan pantang menyerah, (7) keadilan dan kepemimpinan, (8) baik dan rendah hati, dan (9) toleransi, cinta damai, dan persatuan. Jadi nilai-nilai karakter adalah nilai-nilai yang bersifat positif untuk pengembangan perilaku individu kearah yang lebih baik, yang terdapat pada aspek nilai agama dan moral, sosial emosional, dan kognitif, bahasa dan seni.

Hasil dari proses bercerita ialah pengetahuan yang terbentuk pada anak yang mampu memaknai karakter dari berbagai tokoh. Cerita merupakan hasil imajinasi yang disusun untuk dibagikan kepada pendengar. Bercerita memiliki arti penekanan sebuah narasi bahwa seseorang mengatakan sebuah kejadian kepada orang lain. Subyantoro (2013) menjelaskan mengani bercerita. Bercerita ialah strategi sistematis yang berisi aktivitas penyaluran cerita dari pencerita kepda pendengar atau penyimak.

Metode bercerita mampu memperkenalkan ekspresi sedih, marah, senang, dan lucu. Kegiatan ini memberikan pengalaman yang mampu diserap oleh siswa. Oleh karena itu, guru harus mampu bercerita dengan penekanan emosi sehingga mampu menunjukkan mimik dan ekspresi. Ekspresi yang diberikan oleh guru dapat menjelaskan perasaan yang dialami oleh guru. Hal tersebut mampu membuat anak mengenali bentuk emosi yang muncul ketika mendengarkan orang bercerita.

Asfandiyar (2007:2) Storytelling merupakan sarana komunikasi untuk menanamkan nilai-nilai kepada anak tanpa merasa digurui. Proses dalam stoyitelling menjadi penting dalam pembelajaran karena nilai atau pesan dari cerita dapat tersampaikan ke anak dengan menyenangkan. Berlangsungnya proses storytelling secara tidak langsung memberikan peran pendengar untuk mendapatkan pengetahuan. Hal inilah yang membuat anak menjadi senang dalam proses bercerita dan tanpa disadari mengajarkan siswa menyukai buku. Melalui buku khususnya cerita, orang tua dan guru mampu menyampaikan kisah yang dapat memancing ekspresi anak.

Media komunikasi dalam membangun kepribadian anak pada proses storytelling terjadi sebuah penyerapan pengetahuan yang disampaikan kepada audience. Proses ini menjadi pengalaman seorang siswa dan guru bertugas menampilkan kesan menyenangkan pada saat bercerita. Storytelling dengan media boneka jari, dapat digunakan Guru TK dalam memberikan pengalaman yang menyenangkan pada pembelajaran. Bercerita saat ini memang jarang dilakukan. Peran dan fungsinya sudah banyak tergantikan oleh tayangan televisi dan bermain game di komputer. Terlepas dari semua itu, cerita memiliki kekuatan, fungsi dan manfaat berbeda dengan tayangan video lain.

Prosedur Storytelling menurut Itadz (2008:101-116) terdapat beberapa prosedur dalam storytelling, yaitu: a) memilah dan memilih materi bercerita, b) memahami dan menghafal isi cerita, c) menghayati karakter tokoh, dan d) Latihan dan introspeksi. Pemilihan materi harus seuai dengan jenjang sekolah maupun umurnya. Pemahaman mengenai jalannya cerita dengan cara menyimak dengan seksama. Melalui Storytelling mengajari kita untuk mendalami tiap karakter tokoh yang berperan dalam cerita. Melakukan latihan terus-menerus berbarengan dengan instropeksi dalam mendongeng,

Mendongeng atau Storytelling memiliki banyak manfaat. Manfaat dari storytelling ialang siswa mampu mengembangkan imajinasi serta daya berpikir anak dan mengembangkan kemampuan 
berbicara. Manfaat lainnya ialah ialah dapat meningkatkan sarana komunikasi anak dengan orang tua (Noor 2011:53). Orang tua juga dapat berperan dalam mendongeng. Orang tua mencoba membiasakan mendongeng agar siswa mampu jauh dari permainan elektrinik atau pun hal yang mamampu menyita perhatian anak. Mendongeng dilakukan di rumah bertujuan untuk menjalin interaksi anata orang tua dan anak. Dengan mendongeng orang tua mampu mempengaruhi pembentukan karakter anak yang dimulai dari usia dini. Dongeng mampu menghidupkan suatu cerita sehingga anak mampu menciptakan fantasi tersendiri dalam tiap tokoh. Sikap anak yang selalu ingin tau dengan hal-hal yang menurut anak menarik, menjadikan dongeng dianggap efektif untuk membangun pembentukan karakter.

Pendidikan usia dini merupakan upaya yang diperuntukkan pada anak sejak lahir hingga usia enam tahun melalui pemberian stimulus untuk membantu tumbuh kembang jasmani serta rohani anak. Siswa akan memiliki sikap siap dalam memasuki pendidikan selanjutnya. Sudaryanti (2015) menerangkan bahwa pendidikan anak usia dini ialah salah satu bentuk pendidikan yang dapat menentukan kehidupan anak dan bangsa di kemudian hari.

Implementasi pendidikan karakter anak usia dini dilakukan melalui dua kegiatan, yaitu kegiatan terprogram dan kegiatan pembiasaan. Kegiatan terprogram merupakan kegiatan yang dilakukan di dalam kelas dengan berbagai metode, media, dan permainan, sedangkan kegiatan pembiasaan dilakukan dengan pembiasaan, kegiatan rutin, kegiatan spontan, dan kegiatan keteladanan. Setiap kegiatan harus direncanakan dan diadakan penilaian perkembangan peserta didik. Tim Direktorat Jenderal Pendidikan Anak Usia Dini, Nonformal, dan Informal Kementrian Pendidikan Nasional (2012: 7).

TK Senyiur Indah menggunakan Kurikulum 2013 dalam pembelajaran karena merupakan inovasi baru terhadap dunia pendidikan. Konsep pendidikan karakter dirancang untuk melahirkan generasi-generasi yang memiliki perkembangan sesuai dengan kebijakan pemerintah. Proses pembelajaran memperngaruhi hasil belajar siswa. Dengan memaksimalkan proses pembelajaran, siswa harus meningkatkan hasil belajar dengan cara menguasai materi yang disampaikan guru.

Metode storytelling di sekolah membuat siswa semakin cerdas. Metode ini menjadikan cerita sebagai media dalam pembelajaran bahasa. Hal tersebut mampu menjadi sarana dalam melatih siswa menjadi berani dalam mengungkapkan sesuatu. Usaha dalam pembentukan karakter siswa diterapkan di TK Semyiur Indah dengan tujuan membentuk generasi yang memiliki karakter dan morak yang baik.

Penggunaan metode storytelling berpengaruh pada prestasi belajar siswa di kelas karena adanya prosen pembelajaran yang bermakna. Siswa dilibatkan dalam pembelajaran secara aktif. Metode ini memberikan inovasi dalam pembelajaran di TK Senyiur Indah. Pe,mbelajaran tak hanya berpusat pada guru tetapi siswa terlibat didalamnya. Diharapkan metide storytelling mampu meningkatkan pemahaman siswa mengenai profesi apoteker dan obat.

Pendidikan karakter untuk mengatasi degradasi moral bangsa Indonesia di setiap usia, khususnya pada anak usia dini. Cara penerapannya pun beragam, mulai dari bercerita, bernyanyi, memberikan teladan, kebiasaan, dan lainnya. Sejatinya penelitian terkait pendidikan karakter terlebih mengenai anak usia dini beberapa kali sudah dilakukan, akan tetapi masing-masing memiliki keistimewaandan kekhasan. Berdasarkan uraian dari latar belakang di atas, maka dapat 
dirumuskan masalah berikut, bagaimana implementasi metode storytelling bermuatan pendidikan karakter dengan tema kesehatan dan obat pada Peserta Didik TK Senyiur Indah Semarang?

Pendidikan usia dini pada jalur formal salah satunya ialah Taman Kanak-kanak (TK). Tujuan TK ialah membantu siswa mengembangkan potensi diri secara psikis maupun fisik. Potensi diri yang dapat dikembangkan meliputi, kognitif, emosional, bahasa, motorik, fisik, moral dan agama serta kesenian. Hal tersebut dipersiapkan dalam rangka memasuki jenjang Sekolah dasar.

Kecerdasan bahasa dan minat membaca pada anak usia di TK saat ini sudah maju. Permainan storytelling bertujuan mengenalkan anak sesuatu dengan lebih mencairkan suasana untuk merangsang minat baca di usia dini. Sehingga penelitian ini akan difokuskan dalam implementasi metode storytelling bermuatan pendidikan karakter dengan tema kesehatan dan obat pada siswa TK Senyiur Indah Semarang.

\section{METODE PENELITIAN}

Pada penelitian ini metode penelitian yang digunakan adalah Penelitian Tindaklan Kelas (PTK). Peneliti menggunakan tahap perencanaan,ialah proses yang dilakukan untuk merencanakan peningkatan pengetahuan mengenai profesi apoteker dan obat. Pelaksanaan dan pengamatan ialah pelaksanaan tindakan penelitian di kelas sesuai dengan rancangan pembelajaran yang mengacu pada RPP. Dan refleksi ialah mengingat kegiatan yang telah dilaksanakan dari mulai pembelajaran sampai berakhirnya pembelajaran. Jenis penelitian ini bertujuan untuk mengetahui perbaikan kualitas belajar siswa. Perbaikan dilakukan untuk mengetahui peningkatan pembalajaran di kelas. Hal tersebut dilakukan secara sadar agar siswa dan guru lebih siap untuk melakukan kegiatan pembelajaran di kelas.

Subjek yang digunakan dalam penelitian ini ialah siswa TK Senyiur Indah berjumlah 20 siswa. Objek penelitian ini ialah proses pembelajaran dengan tema kesehatan melalui metode storytelling. Tempat penelitian dilaksanakannya penelitian ini ialah TK Senyiur Indah Banyumanik Semarang. Penelitian dilaksanakan pada tahun ajaran 2019/2020 pada bulan agustus 2019. Intrumen penelitian yang digunakan dalam pengumpulan data penelitian ialah, instumen tes dan non tes. Intrumen tes ialah soal berupa pilihan ganda dengan tema profesi apoteker (kesehatan). Instrumen non tes digunakan lembar observai, angket guru dan siswa. Pengumpulan data penelitian ini menggunakan metode tes dan non tes. Metode nontes meliputi observasi dan dokumentasi. Teknik analisis data menggunakan teknik kuantitatif. Indikator keberhasilan penelitian ini ialah, apabila nilai rata-rata siswa $\geq 85 \%$.

\section{HASIL PENELITIAN DAN PEMBAHASAN}

Penelitian ini dilakukan dua siklus, yaitu siklus 1 dan siklus 2. Kegiatan melibatkan guru dan siswa. Kehitan tersebut meliputi kegiatan awal, inti dan akhir. Kegiatan awal, siswa diminta untuk berdoa, presensi, dan appersepsi. Kegiatan selanjutnya ilah kegiatan inti, kegiatan tersebut menggunakan metode storytelling. Kegiatan akhir, siswa diminta untuk saling bertanya jawab dengan guru. Dilanjutkan guru bersama siswa menyimpulkan kegiatan pada hari itu. 
Hasil penelitian menunjukkan storytelling mampu mengembangkan pengetahuan siswa mengenai kesehatan dan obat. Pengenalan kesehatan diimpelmentasikan pada tema profesi, khususnya profesi apoteker. Siswa tertarik dalam proses pembelajaran dengan dibutikan saat observasi selama pembelajaran. Storytelling sangat tepat jika diterapkan pada pembelajaran di TK.

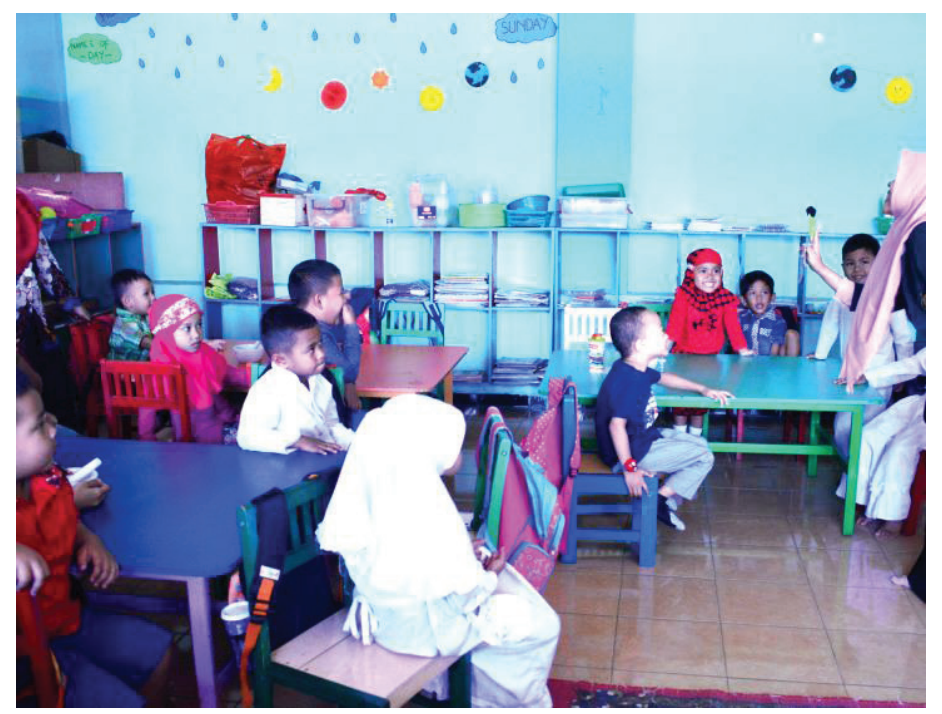

Gambar 1. Proses Pembelajaran dengan Metode Storytelling

Pembelajaran berbantu metode storytelling memberikan efek imajinatif pada siswa. Siswa mampu mengasah kemampuan berkomuniasi melalui mendengarkan dongeng yang disampaikan oleh guru. Kemampuan berimajinasi dan berfantasi memudahkan siswa dalam memahami materi yang disampaikan oleh guru. Hal tersebut sesuai dengan teori bahwa manfaat bercerita salah satunya ilah membantu meningkatkan ilustrasi sesuatu sehingga dapat mengkonkretkan cerita yang disampaikan.

Tabel 1 Nilai Siklus 1 dan Siklus 2

\begin{tabular}{|c|c|c|c|}
\hline No & Nilai & Siklus 1 & Siklus 2 \\
\hline 1 & Terendah & 20 & 80 \\
\hline 2 & Tertinggi & 80 & 100 \\
\hline \multicolumn{2}{|c|}{ Rata-rata } & 59 & 99 \\
\hline
\end{tabular}

Pembelajaran pada siklus pertama, guru menggunakan pembelajaran konvensional. Guru menyiapkan RPP dan menyampaikan secara lisan informasi mengenai obat, kesehatan serta profesi apoteker. Tahapan selanjutnya, guru menyampaikan materi dengan model yang biasa dilakukan. Tahap akhir guru dan siswa melakukan evaluasi dan simpulan materi hari itu. Pembelajaran siklus kedua, guru menggunakan pembelajaran dengan metode storytelling. Guru sudah menyiapkan RPP sebelumnya sehingga sudah siap dengan metode tersebut. Guru memberikan materi mengenai obat dan profesi apoteker dengan cara berdongeng. Siswa didorong untuk mengamati dongeng yang sedang dibacakan. Siswa sangat senang dan benar-benar menyimaknya. Kegiatan akhir, guru 
melakukan tanya jawab kepada siswa mengenai hasil simakan dongeng tersebut. Tanya jawab yang dilakukan mengenai tokoh, jenis obat, dan profesi apoteker.

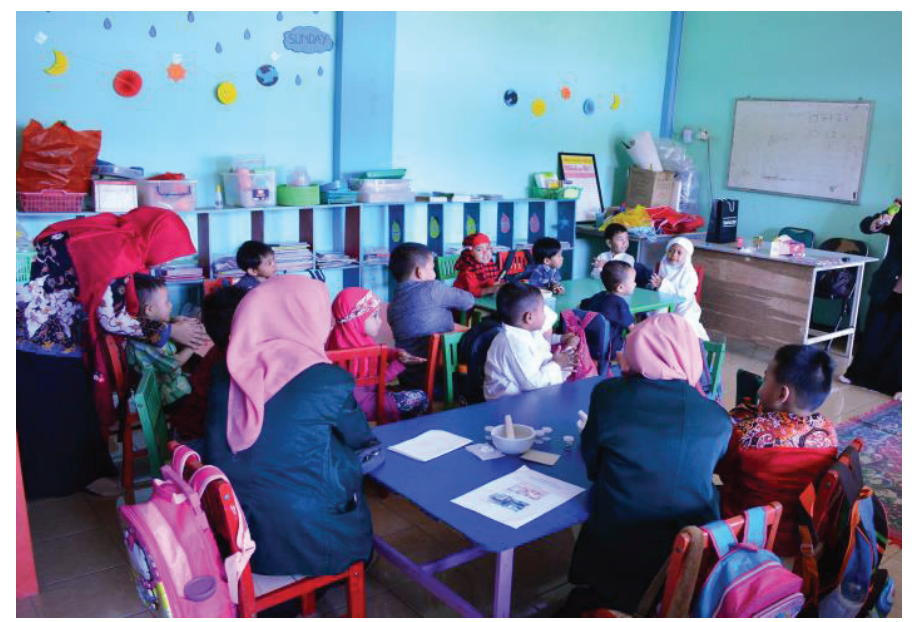

\section{Gambar 2. Siswa Menyimak Dogeng yang Dibacakan}

Hasil penelitian diperoleh peningkatan pengetahuan siswa mengenai hal-hal yang berhubungan dengan profesi apoteker. Dari hal jenis obat, pembeliannya di apotek serta orang yang meracik obat adalah apoteker. Berdasarkan hasil penelitian, diperoleh rata-rana nilai siswa sebelum diberi metode storytelling TK Senyiur Indah adalah 59. Siswa masih belum mampu mengituti pembelajaran dengan fokus. Nilai terendah di kelas tersebut adalah 20 sedangkan nilai tertinggi 80 . Peneliti menggunkana metode storytelling dalam pembelajaran pada siswa TK Senyiur Indah. Siswa memeroleh nilai terendah sebesar 80 pada hasil penilaian Siklus 2, sedangkan nilai tertinggi diperoleh 100 .

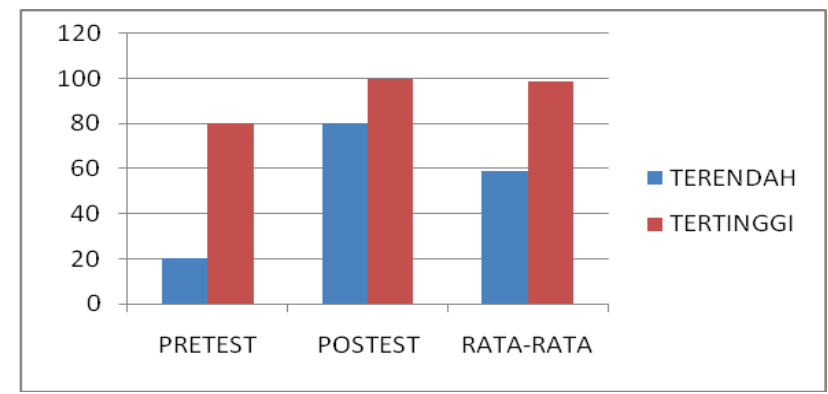

Grafik 1. Nilai Siklus 1 dan Siklus 2

Terdapat peningkatan dalam pembelajaran dengan tema profesi kesehatan pada siswa TK Senyiur Indah. Peningkatan diperoleh dari nilai Siklus 2 dan Siklus 2. Peningkatan sebanyak 40\%. Nilai tersebut diperoleh dari nilai rata-rata Siklus 1 sebesar 59\% dan nilai rata-rata Siklus 2 sebesar 99\% sehingga ada perningkatan nilai secara signifikan. 


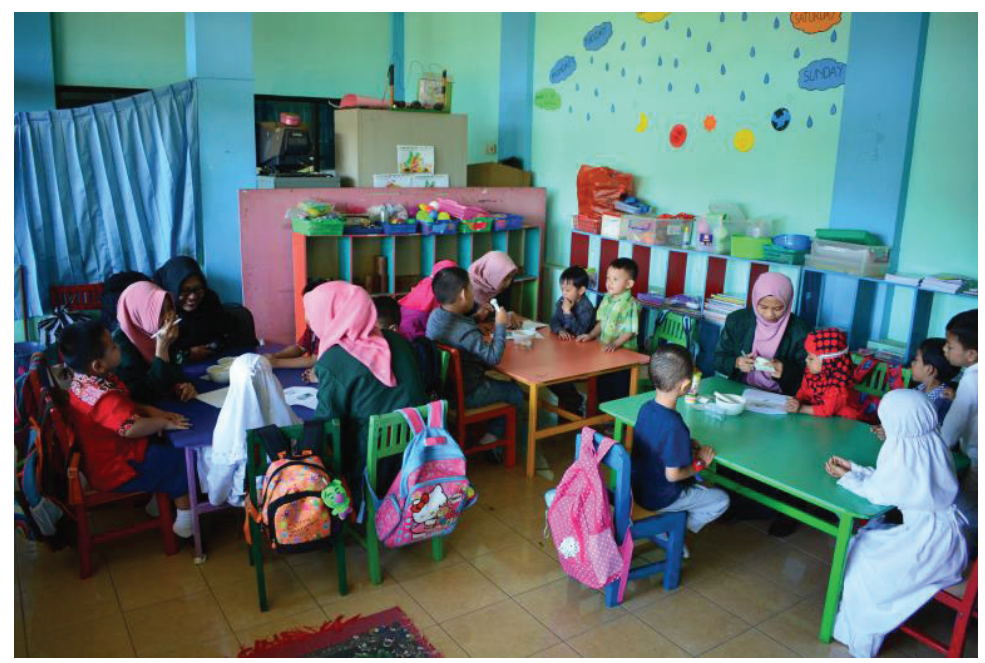

Gambar 3 Proses Refleksi pada Siklus 2

Kriteria keberhasilan pada siklus 2 ditentukan oleh peneliti. Pengetahuan anak mengenai profesi apoteker di tingkatkan melalui metode storytelling bermuatan pendidikan karakter. Cerita yang digunakan disesuaikan dengan tema pembelajaran yaitu profesi apoteker. Cerita juga memiliki muatan pendidikan karakter.

Tabel 2 Peningkatan Nilai Storytelling

\begin{tabular}{|c|c|c|c|c|c|}
\hline No & $\begin{array}{c}\text { Interval } \\
\text { Nilai }\end{array}$ & Siklus 1 & Prosentase & Siklus 2 & Prosentase \\
\hline 1 & $10-39$ & 1 & $5 \%$ & 0 & $0 \%$ \\
\hline 2 & $40-59$ & 5 & $25 \%$ & 0 & $0 \%$ \\
\hline 3 & $60-79$ & 9 & $45 \%$ & 2 & $10 \%$ \\
\hline 4 & $80-100$ & 5 & $25 \%$ & 18 & $90 \%$ \\
\hline
\end{tabular}

Tabel diatas menjelaskan peningkatan pada siklus 2 dilihat dari prosentasi yang diperoleh. Terjadi peningkatan pada siklus 1 ke siklus 2 . Interval nilai siswa pada siklus satu ialah, sebanyak 1 siswa mendapatkan interval nilai 10-39 dengan prosentase 5\%. Interval nilai 40-59 diperoleh sebanyak 5 siswa dengan prosentase 25\%. Terdapat 9 siswa yang mendapatkan nilai antara 60-79 dengan prosentase $45 \%$ sedangkan siswa yang memperoleh nilai 80-100 hanya 5 siswa dengan prosentase $25 \%$.

Siklus 2 mengalami peningkatan yang signifikan dengan uraian, siswa yang mendapatkan nilai antara 60-79 sebanyak 2 siswa dnegan prosentase 10\%. Sedangkan 18 siswa lainnya mendapatkan nilai antara 80-100 dengan prosentase 90\%. Hal tersebut diperoleh setelah mendapatkan pmbelajaran menganai obat dan kesehatan dengan metode strorytelling pada siswa TK senyiur Indah. Hasil tersebut menjelaskan bahwa presentasi pencapaian pengetahuan dengan metode storytelling meningkat pada siklus 1 ke siklus 2 . 


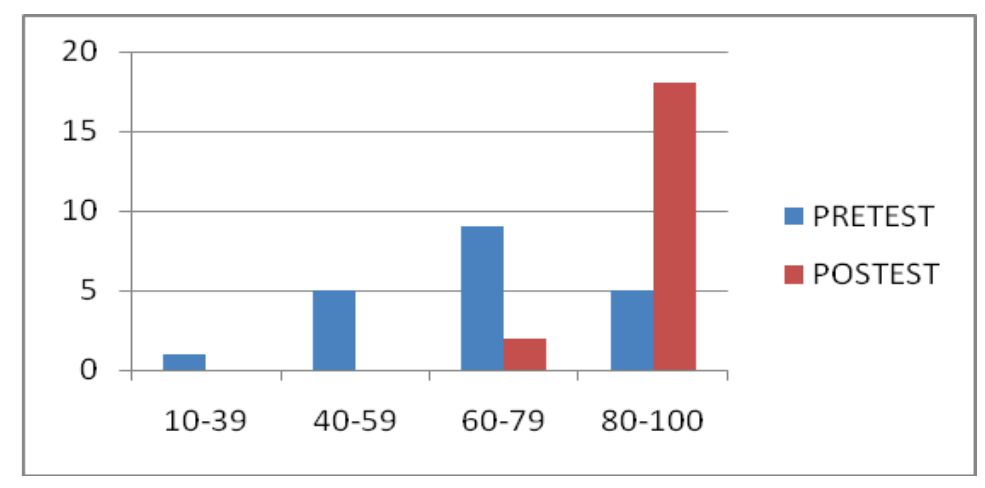

\section{Grafik 2 Peningkatan Nilai Storytelling}

Berdasarkan grafik tersebut dapat dikatakan bahwa metode storytelling mampu meningkatkan hasil belajar siswa. Hal tersebut dapat dilihat hasil rata-rata siswa mendapatkan nilai di bahwah 80 . Terdapat peningkatan pada siklus 2, siswa mampu mendapatkan nilai diatas 80 sebanyak 99\%. Penelitian dikatakan telah tuntas dilihat dari hasil penelitiannya. Peningkatan suasana pembelajaran menjadi menyenangkan dengan menggunakan metode storytelling membuat siswa lebih bergairah dalam belajar. Dengan begitu, guru mampu mengeksplor potensi siswa serta membangun rasa percaya diri. Siswa lebih mampu memahami pembelajaran dengan metode storytelling ini.

\section{PENUTUP}

Berdasarkan hasil penelitian menggunakan storytelling dengan tema profesi, dapat disimpulkan bahwa metode tersebut dapat meningkatkan pemahaman siswa mengenai obat dan profesi apoteker. Penelitian dilakukan dengan dua langkah yaitu siklus satu dan dua. Penelitian ini juga mampu meningkatkan sikap siswa. Sikap yang dapat ditimbulkan ialah sikap menghormati, berani, serta ingin tahu. Sehingga secara tidak langsung, siswa mampu belajar menerapkan nilai karakter.

Peningkatan pengetahuan siswa TK Senyiur Indah dapat ditingkatkan melalui metode Storytelling. Siswa didengarkan cerita mengenai profesi apoteker dan obat. Siswa mendengarkan dengan seksama, memahami serta mengintepretasikan jalannya cerita. Siswa bersama guru melakukan tanya jawab mengenai tema yang sedang diajarkan. Guru mengevaluasi hasil pembelajaran. Siswa diberi reward oleh guru untuk meningkatkan motivasi belajar anak.

Dari hasil penelitian dapat dikatakan bahwa metode storytelling mampu mengembangkan pengetahuan siswa mengenai kesehatan dan obat. Pengenalan kesehatan diimpelmentasikan pada tema profesi. Usia yang potensial dalam pembentukan karakter ialah usia emas. Masa tumbuh kembang usia anak untuk membentuk karakter sekitar usia 0-5 tahun. Peningkatan sebanyak 40\%. Nilai tersebiut diperoleh dari nilai rata-rata Siklus 1 sebesar 59\% dan nilai rata-rata Siklus 2 99\%. Sehingga ada perningkatan nilai secara signifikan. Terdapat peningkatan pada siklus 2, siswa mampu mendapatkan nilai diatas 80 sebanyak $99 \%$. 


\section{DAFTAR PUSTAKA}

Asfandiyar, Andi Yudha. (2007). Cara Pintar Mendongeng. Jakarta: Mizan.

Gunawan, Heri. (2012). Pendidikan Karakter: Konsep dan Implementasi. Bandung: Alfabeta

Itadz. (2008). Memilih, Menyusun, Dan Menyajikan Cerita Untuk Anak Usia Dini. Yogjakarta: Tiara Wacana

Kementerian Pendidikan dan Kebudayaan. (2012). Konsep Dasar Pendidikan Anak Usia Dini. Direktorat jenderal Pendidikan Anak Usia Dini Non Formal Informal: P2PNFI Regional II Semarang Kementerian Pendidikan dan Kebudayaan. 2012. Kurikulum usia 3-4 tahun. Semarang: Direktorat Jenderal Pendidikan Anak Usia Dini Non Formal Informal,P2PNFI Regional II Kementrian pendidikan nasional. 2010. Panduan Pendidikan Karakter di SekolahMenengah Pertama, Kemendiknas.Jakarta: direktorat jenderal mandikdasmen, direktorat pembinaan sekolah menengah pertama

Kristiani, Ary. (2014). Implementasi Pendidikan Karakter pada Pembelajaran Bahasa di PG-TPA Alam Uswatun Khasanah, Sleman, Jogjakarta.Diambil dari http://staff.uny.ac.id/sites/default/files/penelitian/ary-kristiyani-spdmhum/artikelimplementasi-pendidikan-karakter-pada-pembelajaranbahasa-di-pg-tpa-alam-uswatunkhasanah-sl.pdf.

Moleong, Lexy J. (2010). Metodologi Penelitian Kualitatif. Bandung: Penerbit PT Remaja Rosdakarya.

Musfiroh, Tadkiroatun. (2008). Memilih, Menyusun, dan Menyajikan Cerita untuk Anak Usia Dini. Yogyakarta: Tiara Wacana

Mulyana, Rohmat. (2004). Mengartikulasikan Pendidikan Nilai. Bandung: Alfabeta

Noor, Rohinah M. 2011. Pendidikan Karakter Berbasis Sastra: solusi pendidikan moral yang efektif. Yogyakarta: AR-RUZZ MEDIA.

Subyantoro. (2013). Pengajaran Bercerita: Model Bercerita untuk Meningkatkan Emosi dalam Berapresiasi Sastra. Yogyakarta: Penerbit Ombak.

Sudaryanti, 2015. Pentingnya pendidikan karakter bagi anak usia dini. Diambil pada journal.uny.ac.id/index.php/jpa/article/view/2902/2416. diakses pada tanggal 9 Februari 2016

Sugiyono. (2010). Metode Penelitian Kuantitatif Kualitatif \& RND. Bandung: Alfabeta

Sujiono, Bambang dan Yuliani Nurani. (2005). Mencerdaskan Perilaku Anak UsiaDini Panduan Bagi Orang Tua dalam Membina Perilaku Anak Sejak Dini. Jakarta: PT. Elex Media Komputindo 